\title{
Os heróis de O Guarani e de Boca do Inferno: a construção das personagens como matéria-prima para o romance histórico \\ $\operatorname{pg} 42-54$
}

Kelcilene Grácia-Rodrigues ${ }^{1}$

Enedir da Silva Santos ${ }^{2}$

\section{Resumo}

O romance histórico estabelece um diálogo entre a historiografia oficial e a ficção. Nele, a liberdade ficcional traça outros caminhos para as personagens. Tendo como corpus os protagonistas Peri, de O Guarani (1857), de José de Alencar, e Gregório de Matos, de Boca do Inferno (1989), de Ana Miranda, demonstramos como as personagens das duas narrativas são arquitetadas a partir do discurso historiográfico real, ainda que em períodos e contextos diferentes, com o objetivo de criarem novos sentidos e releituras que marcam a postura do brasileiro ante o colonizador. Para tanto, nos valemos dos estudos teórico-críticos de Candido (1976, 2000), Lukács (2000, 2011), Benjamin (1991), Hutcheon (1991), Doody (2009), Jameson (2007), Weinhardt (1994), Esteves (2008, 2010), entre outros.

Palavras-chave: Ficção brasileira. Romance histórico. José de Alencar. Ana Miranda.

\section{THE HEROES OF O GUARANI AND BOCA DO INFERNO: THE CONSTRUCTION OF RAW MATERIALS AS CHARACTERS FOR HISTORICAL NOVEL}

\begin{abstract}
The historical novel establishes a dialogue between official historiography and fiction. In this genre, fictional freedom traces other paths to the characters. Having as corpus the protagonists Peri, from $O$ Guarani (1857), by José de Alencar, and Gregorio de Matos, from Boca do Inferno (1989), by Ana Miranda, we intend to show how the characters of the two narratives are built, although in periods and different contexts, with the aim of creating new meanings and re-readings that mark the position of the Brazilian before the colonizer. In order to carry out this analysis, we use the theoretical-critical studies of Candido (1976, 2000), Lukács (2000, 2011), Benjamin (1991), Hutcheon (1991), Doody (2009), Jameson (2007), Weinhardt (1994), Esteves (2008, 2000), among others.
\end{abstract}

Keywords: Brazilian Fiction; Historical Novel. José de Alencar. Ana Miranda.

\footnotetext{
1 Docente do Curso de Letras e do Programa de Pós Graduação em Letras da Universidade Federal do Mato Grosso do Sul UFMS)/Campus de Três Lagoas, Brasil. E-mail: kelcilenegracia@gmail.com

2 Doutoranda em Estudos Literários da Universidade Federal do Mato Grosso do Sul (UFMS)/Campus de Três Lagoas, Brasil. E-mail: enedirss@hotmail.com
} 
Em que ponto se entrecruzam realidade e ficção? Existe um lócus central de coesão do real com sua representação? Qual a base de sustentação da ficção historiográfica? Esses três questionamentos encontram um lugar comum em suas respostas: a personagem.

A força e as atitudes de pessoas reais são matéria-prima para a construção de narrativas históricas. Por outro lado, a arte literária valese dos fatos da realidade para arquitetar uma narrativa paralela, sedimentar e basilar, de maneira que origina uma trama em decorrência de ações e atitudes dos homens da realidade factual.

A História, enquanto ciência, é composta por narrativas de reconstrução nas quais a força das personas é determinante. Já a Literatura, enquanto expressão artística, constrói uma mimese, ainda que fundamentada no real, que usufrui da ficcionalidade e promove um mergulho do leitor na interioridade humana, com a segurança da onisciência, porque é romance, e não história.

Nesse sentido, Candido, em Literatura $e$ sociedade (2000), assevera que a produção literária brasileira tem consistido em uma constante superação de obstáculos, em que o intelectual brasileiro está defronte a particularidades do meio, raça, história e geografia. Dessa maneira, muitas vezes, buscando identificar-se com esta civilização, cheia de particularidades, ele se distancia dos padrões europeus, que, como se sabe, serviram de referência para vários escritores brasileiros. O tempo e o amadurecimento do fazer literário puderam distanciar os escritores brasileiros dos moldes europeus e inaugurar uma temática brasileira com um olhar tão nacionalista quanto.

Conforme preconiza Lukács, (2011, p. 235) ao se figurar o real, essa realidade, enquanto dialética, se apresenta na escrita "como uma mistura de exotismo exterior e modernidade interior, relevante para a evolução artística”, promovendo um ganho com o enriquecimento linguístico. $\mathrm{O}$ literário, portanto, investido de realidade em seus constructos, estabelece novos universos, com suas generalidades, suas especificidades oniscientes e finalidades críticas, além de estéticas, retrata, de forma ficcionalizadas, fatos e pessoas reais.

Resgatar o passado pela ficção escrita no presente é uma "arma” para o romancista, principalmente quando ele consegue o equilíbrio entre fantasia e realidade, em que os jogos inventivos, termo utilizado por Esteves (2008), aplicados ao contexto histórico fornecem ao leitor concomitantemente a ilusão de escapar à realidade insatisfatória e ter a ilusão de realismo.

É o que acontece nas obras O Guarani, de José de Alencar, e Boca do Inferno, de Ana Miranda, que instigam análise aproximativa a partir das personagens protagonistas: Peri e Gregório de Matos. Por meio das personagens, os autores retomam fatos e acontecimentos reais para a composição de uma literatura brasileira crítica, de esteira historiográfica inconfundível.

Para fazer uma leitura atenta e em clave comparatista entre os dois romances, especialmente sobre as personagens, é preciso considerar os diferentes estilos, contextos e conjunturas nacionais em que as narrativas foram criadas e a que se referem. No romance alencariano, a miscigenação do índio com o branco; em Ana Miranda, a luta pelo poder, a libertinagem e a acidez poética como veia de denúncia.

Interessa-nos perceber que em ambos os romances abordados neste trabalho temos momentos ímpares da história oficial brasileira: os bandeirantes e a servidão devida ao fidalgo português; os desmandos e os vícios dos representantes da coroa portuguesa em solo brasileiro durante a colonização, além da inquisição e do comprometimento do clero com a situação política do país. Os enredos retomam fatos reais 
que são reconfigurados de modo arquitetônico e metafórico, para revelar, a partir das personagens, a construção identitária de um país colonizado.

As origens do romance histórico remontam aos séculos XVII e XVIII, mas sem muita representatividade. Em O romance histórico, Lukács (2011) evidencia que as narrativas com essa vertente se preocupavam, no início, mais com fatos históricos do que com o fazer literário. Oficialmente, o romance histórico nasce no século XIX com Ivanhoé de (1819), de Walter Scott. Esse tipo de romance é resultado de um contexto histórico e econômico em que num misto de insatisfação e resiliência originaram certa convulsão do ser e da consciência dos homens em todo o território europeu. Conforme Esteves, a narrativa de Scott prima por dois princípios básicos:

O primeiro deles é que a ação ocorre num passado anterior ao presente do escritor, tendo como pano de fundo um ambiente histórico rigorosamente reconstruído, onde figuras históricas ajudam a fixar a época. Sobre esse pano de fundo, situa-se uma trama fictícia, com personagens e fatos inventados pelo autor. (ESTEVES, 2008, p. 58).

Tais princípios se configuram como uma fissura entre os romances históricos antecedentes ao de Walter Scott, pois se nos primeiros não havia preocupação com o fazer literário, no segundo, há uma valorização das ações individuais das personagens. O coletivo é afetado pelo contexto histórico, o protagonismo que advém do povo e não da história, ilustra essa ruptura, pois a personagem principal torna-se uma das peças chave do romance histórico, um herói além do povo, um ícone do conflito que está exposto, ficcionalmente, no terreno literário.

Dessa forma, para que possamos compreender o contexto de produção do romance histórico, tomamos novamente as palavras de Antonio Esteves, que em consonância com vários estudiosos desse tipo de romance, caracteriza-o como uma epopeia da burguesia da época, em que os fatos geradores de tensão, também gerariam certa negação do fatídico, em que "criar essa nova variante, cujos personagens, ao mesmo tempo em que estão profundamente inseridos no fluxo da história, atua, de modo que seu comportamento explicite as peculiaridades da época apresentada" (ESTEVES, 2010, p. 31).

No Brasil, o romance histórico surge também em um momento de mudanças e conflitos: a Independência. Tal momento gerou um romance pronto a ecoar patriotismo, a exalar cultura nacional, além de tornar-se uma vitrine para propagar a liberdade conquistada. Nesse contexto, a possibilidade de diálogo entre o tratamento histórico do passado acena para o escritor como uma forma de abordagem criativa até certo ponto livre, pois para construir sua narrativa, ele usufrui dos fatos passados e pode ultrapassá-los, como nos assevera Marilene Weinhardt: "A conclusão é de que talvez o passado histórico nada mais tenha a nos dizer, mas a ficção histórica permite ao escritor fugir das armadilhas e das imposturas do eu" (WEINHARDT, 1994, p. 52).

Escrever romances históricos no século XXI é contar com um arcabouço imenso de personagens, conflitos, temática, ou seja, um material que pode transfigurar-se de discurso histórico tradicional em obra fictícia. O escritor pode buscar seus protagonistas entre as figuras ilustres ou dentre os marginalizados, ou seja, ele pode agir como um demiurgo dos destinos das personagens.

A volta ao passado é um recurso que notadamente aparece em alguns romancistas contemporâneos, mas no romance brasileiro tem seu marco inicial com as obras de José de Alencar, tais como O Guarani (1857), As minas de prata (1862), Iracema (1865), entre outras, que apresentam o encontro entre as diferentes culturas, a natureza exacerbadamente descrita, além da sentimentalidade que justifica 
alguns sacrifícios, o que veremos amplamente evidenciado no índio Peri.

Se no século XIX destacamos a obra de Alencar, no século XX buscamos traços do romance histórico nos textos de Ana Miranda e eles surgem aos borbotões em Boca do Inferno (1989), O retrato do rei (1991), Desmundo (2006), entre outros romances da escritora, que evocam (ou não) personagens ilustres do discurso historiográfico.

Enquanto os romances de José de Alencar têm um expansivo fundo nacionalista, os de Ana Miranda evocam personagens marginalizadas, ou pelo menos, retratadas dessa forma, para evidenciar que o Brasil não é o paraíso tropical evocado pelo Romantismo. Em Boca do Inferno, a personagem Gregório de Matos destila em seus versos o veneno contra os governantes apoiados pela coroa portuguesa, além de evidenciar as intrigas, corrupções e devassidões que ocorriam na Bahia do século XVII.

Em Peri, de O Guarani, temos um "bom selvagem", que enamorado, devota sua vida para servir a Cecília e sua família. Índio dominado pelo colonizador, a personagem torna-se mais civilizada pelo convívio com os portugueses: não é inteiramente índio, nem inteiramente português, está em constante trânsito entre esses dois mundos. Em contrapartida, Gregório de Matos, de Boca do Inferno, é o boêmio, o voluptuoso e o devasso poeta que se opõe ao governo colonial. Longe da figura do herói tradicional, Gregório é um anti-herói que luta com seus valores autênticos contra o mundo degradado de injustiças e colonização.

Mesmo produzindo seus romances em épocas distintas, José de Alencar e Ana Miranda têm em comum a utilização da história como um intertexto para suas ficções, ou seja, ficcionalizam lacunas que o discurso historiográfico não conseguiu preencher, ou ainda, utilizam tais lacunas como material de sua escrita, lugar em que desenvolvem suas tramas. Nessas produções, observamos características dos textos de Walter Scott, como destacadas por Antonio Esteves:

1. A ação ocorre em um passado anterior ao presente dos escritos, tendo como pano de fundo um ambiente rigorosamente reconstruído, onde figuras históricas ajudam a fixar a época. Sobre esse pano de fundo situase uma trama fictícia, inventada pelo autor. 2 . Os romances de Scott e seus seguidores, bem ao gosto romântico, costumam introduzir na trama ficcional um episódio amoroso geralmente problemático cujo desenlace pode variar, ainda que, na maioria das vezes, termine trágico [...] (ESTEVES, 2010, p. 31-32)

Já a teoria sobre o romance histórico contemporâneo parece mais focada no quão produtivo pode ser o encontro entre a história e a literatura do que nas diferenças que as separam, como está exposto nas considerações de Linda Hutcheon:

Considera-se que as duas obtêm suas forças a partir da verossimilhança, mais do que a partir de qualquer verdade objetiva; as duas são identificadas como construtos linguísticos, altamente convencionalizadas em suas formas narrativas, e nada transparentes em termos de linguagem ou de estrutura; e parecem ser igualmente intertextuais, desenvolvendo os textos do passado com sua própria textualidade complexa (HUTCHEON, 1991, p. 141).

Nos romances aqui analisados, veremos que a complexidade do texto recai sobre as personagens protagonistas, partimos dessa premissa por entender os protagonistas como aqueles que fazem esse traslado entre história e literatura, unindo as duas pontas e influenciando o caminhar romanesco. De um lado o selvagem servil, do outro o poeta maldito e no meio deles, o romance histórico transportando-os para as tramas literárias.

\section{O homem e a história: uma só matéria- prima}

O homem e a história, enquanto narrativas, estão vinculados de tal forma, que mesmo sem ater-se, o homem é protagonista de eventos que se solidificam tanto na historiografia oficial quanto na 
ficção, assim como conduz o fio narrativo como agente e interagente.

A retomada de fatos históricos do passado pela ficção literária é recurso estilístico que tem chamado atenção de estudiosos da área, haja vista o número elevado de artigos publicados sobre narrativas com tal abordagem. $\mathrm{Na}$ visão de diversos teóricos, esse resgate propicia análises do presente e torna-se tarefa essencial nas pesquisas literárias, principalmente, quando os textos investigados contêm em si um equilíbrio entre fantasia e realidade, os chamados jogos inventivos, termo utilizado por Esteves (2008), e que aplicados ao contexto histórico fornecem ao leitor, concomitantemente, a ilusão de escapar à realidade insatisfatória e, mesmo assim, manter certa ilusão de realismo, promovendo novos posicionamentos, quiçá, engajamento diante das questões abordadas.

A capacidade do texto literário em propiciar reflexões além das linhas que o encerram é o que encontramos em O Guarani e Boca do inferno, ambos se orientam a partir de personagens protagonistas masculinas. Peri, um índio dotado de extremo servilismo ao português, preservando ao mesmo tempo a figura heroica do indígena valente e o aspecto selvagem; Gregório de Matos, um poeta do século XVII, contestador eloquente que denuncia a violência ocorrida na Bahia, sem isentar Portugal dos malefícios provocados.

Interessa-nos reiterar que nestes romances temos momentos ímpares da historiografia oficial: os bandeirantes e a servidão devida ao fidalgo português; os desmandos e os vícios dos representantes da coroa portuguesa em solo brasileiro durante a colonização, além da inquisição e dos vícios dos quais o clero não escapava em terreno tupiniquim.

É nesse sentido que a ficcionalização da historiografia propicia reflexão e amplia os horizontes do leitor, pois se entende que as personagens protagonistas e os acontecimentos históricos formam elos que compõem e direcionam o material do romance. Isto é, distanciado-se da figura real do índio brasileiro pelo servilismo devotado ao português, percebemos Peri como uma representação do dominado que, iludido pela submissão, assume como função a proteção à família portuguesa.

Já em Boca do Inferno ${ }^{3}$, Ana Miranda condensa na personagem não somente a vivência e as excentricidades do poeta Gregório de Matos. O protagonista assume na narrativa uma perspectiva de denúncia em que as inúmeras tramas políticas são reveladas em sua poesia. Os conteúdos disseminados de boca em boca evidenciavam os abusos da coroa portuguesa, as contravenções dos cidadãos baianos e de seus governantes, os vícios do clero, além de um enfoque especial dado à figura do padre Antônio Vieira, outro protagonista do romance, mais político do que religioso.

Os recortes feitos pelos romancistas a partir da representação dos protagonistas suscitam, a partir do texto literário, reflexões sobre o papel do índio, enquanto sofredor de violências empreendidas pelos portugueses, assim como o do poeta, como denunciador e, ao mesmo tempo, perseguido por ser a boca que revela as verdades encobertas pelo colonizador.

Assim, podemos verificar a força e a distinção entre as personagens que conduzem as histórias. São personas que atuam como elementos essenciais para a composição da ficção, levando o leitor a mergulhar nas tramas narrativas que se embaraçaram nas tramas históricas. Conforme preconiza Candido (1976, p. 53), “É uma impressão praticamente indissolúvel: quando pensamos no enredo, pensamos simultaneamente nas personagens; [...] O enredo existe através das personagens; as personagens vivem no enredo".

3 Eunice de Morais (2003) e Denis Pereira Martins (2015) desenvolvem estudos aprofundados sobre Boca do Inferno como romance histórico. 
Homem ehistória se integram no rolde tecidos literários que os tornam clássicos, por sua qualidade iconográfica e por trazerem à luz o determinante, o factual, o verdadeiro, sem comparações com o passado, mas sendo o próprio passado, da maneira mais original. Pois, conforme questiona Linda Hutcheon, "como pode o romancista verificar qualquer relato histórico por comparação com a realidade empírica do passado a fim de testar a validade desse relato?" (HUTCHEON, 1991, p. 162). A autora afirma que embora o passado tenha existido, de fato, o acesso a ele, "está condicionada a sua existência como texto".

\section{A difícil configuração da força das personagens históricas}

Como vimos, o homem é matéria prima para a arquitetura da narrativa. Em O guarani e Boca do Inferno, percebemos que o homem é o eixo central do enredo. Ocorre que a escrita é arte exigente, posto que se insere na própria realidade que utiliza como matriz geradora da mimese. Por isso, no processo de arquitetura da narrativa, tarefa árdua para o romancista, é preciso considerar a intencionalidade na composição da personagem que se coaduna ao enredo no intuito de "transver" o mundo a partir da obra literária.

No constructo artístico, delineia-se o traço de uma formação indefinida, com acentuada relação presença/ausência - ou concretude/ abstração - também observável na noção de imagem/metáforas, ações, coragem, falácias, tudo conflui para o campo das imagens. Nesse aspecto, Walter Benjamin teoriza que "[a]quilo que sabemos que, em breve, já não teremos diante de nós, tornase imagem.” (BENJAMIN, 1991, p. 85). Portanto, se a história é uma sequência de imagens; assim também o é o literário.

Nessa linha de raciocínio, é oportuna a observação do pensador alemão quando afirma que por ser dotado dessa consciência é que o romancista habilita-se a conhecer o seu povo para extrair desse conhecimento a sua forma singular de "verdade histórica" na qual inclui a personalidade do protagonista.

Desse modo, refletir sobre a constituição dos protagonistas nos textos ficcionais, a compleição de cada um, a força determinante que devem ter para justificar sua escolha na condução do relato, confirma as palavras de James Wood de que é possível aprender muita coisa sobre uma personagem pela maneira como ela fala e com quem fala - "como el[a] lida com o mundo". (WOOD, 2011, p. 87). Nas narrativas de Alencar e Miranda, constatamos que são objetivas as personas dos protagonistas e se mobilizam, do campo historiográfico para o ficcional, como elementos de destaque para o contexto, pois centralizam tanto as outras personagens, quanto os acontecimentos do enredo.

A título de exemplo, citamos a articulação do protagonista com outras personagens em Boca do Inferno. Ao redor de Gregório de Matos orbitam, entre outros, o Padre Antônio Vieira, com os sermões e cartas críticas, Antônio de Sousa Menezes, governador da Bahia, que integram um extenso painel intelectual, psicológico e mental. O que diferencia cada personagem é o que este instiga no leitor, que busca na incompletude de cada uma os efeitos do passado, do que passou e aconteceu um dia, para o entendimento dos dias presentes. O romance histórico, portanto, mais do que uma modalidade, um recorte, assume a posição de ferramenta literária para leitura do tempo pretérito.

Dessa maneira, tanto a narrativa de O Guarani quanto de Boca do Inferno dispõem de protagonistas que centralizam as ações e as ressignificam: Peri, um herói nacional, vitrine de um selvagem poético; Gregório, um poeta boêmio, que em vocabulário agressivo contesta o povo baiano e suas autoridades, constituindo-se como um anti-herói cujo caráter 
é corrompido por uma imensidão de vícios. Essa ressignificação advém das características que compõem cada protagonista, como assevera Margareth Doddy:

De fato, as personagens dos romances são, desde o início (pelo menos para os leitores, mas também para os escritores, embora nem sempre em nível consciente), figuras ou signos de determinadas qualidades ou abstrações: vícios, virtudes, opiniões políticas, posições sociais, questões de sexo e comportamento mais ou menos adequados a eles (DOODY, 2009, p. 563).

É isso que fazem Alencar e Miranda ao elegerem, respectivamente, Peri e Gregório de Matos como seus protagonistas em narrativas com forte apelo historiográfico: transpõe para o texto, um herói e um anti-herói com fortes vínculos com seus grupos sociais, inclusive com uma postura que encarna a vida prática em cada contexto.

José de Alencar buscou na criação narrativa mostrar a realidade brasileira de sua época, exibindo num belo e exótico Brasil a figura do índio. Por meio da constituição do protagonista Peri, a narrativa alude a fatos da construção nacional, como a questão da miscigenação racial, que é basilar na identidade do povo brasileiro.

No romance alencariano, a caracterização do Brasil evidencia um reflexo especular da Europa medieval, o que se nota a partir da arquitetura do palacete de D. Antônio de Mariz que é uma mescla da arquitetura colonial brasileira com a de um castelo medieval europeu. $\mathrm{O}$ dialogismo e as relações dessa personagem secundária com a de seus empregados segue os moldes feudais nos quais o senhor tem com seus vassalos.

No romance Boca do Inferno, Ana Miranda tem como proposição, na linha de romance histórico, mais do que construir uma trama cheia de conspirações políticas, aventuras, além de alta dose de sexualidade ambientada no Brasil colonial. Demonstra que há raízes e fontes seminais para as chagas do país de hoje. Nesse sentido, a obra vai muito além de Salvador de 1683, e mais longe ainda das venturas e desventuras vividas pelo poeta barroco Gregório de Matos - personagem-título em torno da qual as cenas se desenvolvem. Ao recriar a Bahia do século XVII, o relato abre-se numa diversidade de novos sentidos, que historicamente coloca o contemporâneo como parte integrante dessa trajetória cronotópica.

Em O Guarani e Boca do Inferno, a literatura e a história se fundem para criar novos sentidos e releituras críticas naquilo que marca as origens brasileiras da libertinagem, da corrupção e da luta pelo poder. Teoricamente é possível invocar, para amalgamar tal assertiva, a teoria de George Lukács (2011), para quem o romance histórico é um gênero que se consagra por revelar forças sociais em disputa, exatamente o que se observa nas narrativas de Alencar e Miranda, em que são latentes as forças sociais.

\section{O indígena: ente servil ou a personificação do herói?}

Em palavras anteriores, vimos que a literatura que se passou a produzir no Brasil pós Independência visava romper os laços com a literatura portuguesa, refletindo no campo das letras o que aconteceu no político. Acerca disso, Candido defende que:

Ser bom, literariamente, significava ser brasileiro; ser brasileiro significava incluir nas obras o que havia de específico do país, notadamente a paisagem e o aborígene. Por isso o Indianismo aparece como timbre supremo de brasilidade, e a tarefa crítica se orientou, desde logo, para a sua busca retrospectiva, procurando sondar o passado para nele localizar os verdadeiros predecessores, que segundo os românticos teriam conseguido, graças principalmente ao pitoresco, romper a carapaça da convenção portuguesa (clássica) (CANDIDO, 2000, p. 171, itálicos do autor).

Dessa forma, José de Alencar como representante do Romantismo não foge à risca e traz como protagonista de suas obras, entre outros, 
a famosa Iracema "a virgem dos lábios de mel” e Peri “o bom selvagem", que reforçam a ideia de conferir brasilidade à literatura da época. Por isso, compreendemos que em O Guarani, como romance histórico, temos não um retrato fiel da história brasileira do período, mas uma ficção que alude ao ideário nacionalista desse período.

Nesse enfoque, podemos apreender Peri como uma manifestação de uma visão que defende a figura do índio como alguém que pode ser civilizado, cujas origens não se apagam, mas podem se adequar à sociedade. Marilene Weinhardt, no artigo "Considerações sobre o romance histórico", defende que o romance histórico não é uma repetição de grandes acontecimentos, mas uma recuperação poética das experiências vividas naquele contexto histórico, visto que "[e]le deve fazer com que o leitor apreenda as razões sociais e humanas que fizeram com que os homens daquele tempo e daquele espaço pensassem, sentissem e agissem da forma como o fizeram” (WEINHARDT, 1994, p. 51).

$\mathrm{Na}$ esteira do pensamento de Weinhardt, percebemos que o "bom selvagem", diante do contexto de produção do romance alencariano, é uma vitrine na qual se constata que o habitante natural do Brasil está pronto a minimizar sua cultura e sua formação para ceder aos ideais de seu colonizador, dessa forma, coexistindo entre colonizadores e colonizados.

Em O Guaranit há dois protagonistas - Ceci e Peri - que são distintos em gênero, nacionalidade e cultura. De um lado, a base portuguesa que deve ser suplantada para que se edifique a raiz brasileira, que, conforme Candido (2000), é resultado da ânsia de se aprofundar o passado em busca de uma realidade própria que demonstre a mesma dignidade dos velhos países.

4 Para o presente estudo, utilizamos a edição do romance publicada em 1966.
Nesse contexto, Ceci é o símbolo da civilidade portuguesa: dócil, submissa, amada e protegida pelas muralhas de sua residência. Aliás, embora descrita como maravilhosamente natural, a terra brasileira era povoada por muitas ameaças. Ceci via Peri com tanta desconfiança quanto os outros; inclusive, muitas vezes, tratando-o como um animal, sempre pronto a realizar as vontades da moça.

Entretanto e de certa forma, o índio descrito por Alencar nos parece uma tentativa de enaltecer uma das raízes da população brasileira. Como personagem, reveste-se de características muito peculiares e um tanto contraditórias, visto que o cenário que a rodeia é praticamente inexplorado, selvagem. Embora a personagem em discurso direto também se assuma selvagem, está domesticada (em alguns aspectos) pelo convívio com o português, o que podemos observar em trechos abaixo:

Peri, primeiro de todos, tu és belo como o Sol, e flexível como a cana selvagem que te deu o nome; as mulheres são tuas escravas. (ALENCAR, 1966, p. 115)

- Peri é um selvagem, filho das florestas; nasceu no deserto; no meio das cobras; elas conhecem Peri e o respeitam. (ALENCAR, 1966, p. 153)

- Peri só, defenderá sua senhora; não precisa de ninguém. É forte; tem como a andorinha as asas de suas flechas; como a cascavel o veneno das setas; como o tigre a força do seu braço; como a ema a velocidade de sua carreira. Só pode morrer uma vez; mas uma vida lhe basta. (ALENCAR, 1966, p. 193)

- Peri é um selvagem, disse o índio tristemente; não pode viver na taba dos brancos (ALENCAR, 1966, p. 358).

Percebe-se que a personagem criada por Alencar representa a ruptura histórica entre Portugal e Brasil, pois a figura indígena que originou a personagem distancia-se consideravelmente do comportamento que Peri manifesta no decorrer do romance, isto porque para compor uma personagem há que se entender que se trata de alguém que mesmo inspirado por um ser existente não passa de [...] "uma pessoa real filtrada pelas lentes da memória e da imaginação, subordinada 
à composição do livro, tendo o romancista de aumentar ou diminuir ou mesmo apagar seus traços mais marcantes, segundo o ritmo e a necessidade estrutural da obra" (DOURADO, 1973, p. 104).

Para reforçar as peculiaridades do indígena, alguns recursos foram utilizados por Alencar, tais como a excessivo descritivismo que alia a personalidade do protagonista, um selvagem aos olhos dos brancos, à paisagem também selvagem. Peri é um inadaptado: transita no mundo dos portugueses, mas não é um deles; vive como um índio, porém, é civilizado.

Desse modo, o autor leva o leitor a desbravar tanto as minúcias do comportamento de Peri, quanto à riqueza paisagística da terra brasileira. Ou seja, enquanto os brancos se refugiam numa fortaleza inacessível, o habitante das matas está integrado ao ambiente em que vive.

Tinha-lhe bastado a luz do seu facho e o canto do cauã que ele imitava perfeitamente, para evitar os répteis venenosos que são devorados por essa ave. Com este simples expediente de que os selvagens ordinariamente se serviam quando atravessavam as matas de noite, Peri descera e tivera a felicidade de encontrar presa aos ramos de uma trepadeira a bolsa de seda, que adivinhou ser o objeto dado por Álvaro (ALENCAR, 1966, p. 153).

Assim, se compreende que o comportamento civilizado de Peri, sua lealdade aos que poderiam ser considerados seus inimigos, sua escravização motivada por amor, refletem, de certa forma, os valores do fidalgo português. Diferente dos outros índios, Peri conhece seu habitat, integra-se a ele, ou seja, mesmo livre, como o país, continua sendo olhado às avessas, sempre com uma pontinha de desconfiança.

A supervalorização da natureza aliada à personagem corrobora para sua composição e trajetória no contexto do romance histórico. Além disso, como um belo romance romântico o desfecho não poderia ser diferente: o amor dignifica tudo, até mesmo a morte. O que resulta dessa aliança é a figura de um herói. Em O Guarani, Alencar serve-se da figura do índio para enaltecer as características da independente nação brasileira, mas não o consegue completamente. A figura indígena tem muito dos valores portugueses, é inclusive representada por esse olhar, representação acrescida de uma grande pincelada de um amor romântico e servil.

\section{O boêmio poeta: um herói problemático}

Boca do Inferno ${ }^{5}$, de Ana Miranda, apresenta duas personagens protagonistas duais: o poeta Gregório de Matos e o padre Antônio Vieira. O primeiro é a personificação da devassidão; o segundo, da retórica influente. Embora os dois romances que analisamos sejam históricos, é preciso ressalvar que o de Miranda deriva de uma série de pesquisas - apontadas na bibliografia no final do volume - e de processos intertextuais que abrangem textos históricos, literários e religiosos.

Como boêmio e devasso, a personagem de Gregório de Matos é um homem de muitas paixões, rendido à libertinagem, mas não alheio à sociedade da qual faz parte. A personagem se compõe com um senso de justiça que o obriga a denunciar e a reparar os males que atingem os que ele considera inocentes no contexto político e social da Bahia do século XVII.

O povo baiano é um misto, no aspecto social, de tudo que há e se encontra no Brasil da época: corrupção, violência, injustiças sociais. Diferentemente de Peri que usa sua astúcia para não magoar Ceci e continuar próximo da família da moça, o poeta não se furta aos escândalos, na verdade, é porta voz de todos eles, distanciando-se cada vez mais da figura do herói.

Aliás, na obra de Miranda, os protagonistas e os narradores denunciam, com recorrência, essa miscigenação do povo brasileiro e essa imigração

5 As citações desta obra de Ana Miranda remetem a edição publicada em 2006. 
pós-descobrimento - século XVI e XVII. Em Desmundo (1996), o narrador nos apresenta um Brasil formado pelos portugueses marginalizados que aqui chegavam para usufruir desta terra. Diante dessa formação, não poderíamos esperar que Gregório de Matos fosse um herói que redimisse a terra brasileira, ele se constitui como mais um dos anti-heróis que integram a massa populacional do país.

Mesmo Gregório de Matos sendo um poeta importante para a literatura brasileira, é preciso distanciar o poeta real do poeta protagonista de Miranda, simplesmente porque a autora tem em seu fazer literário a chance de moldar sua personagem como melhor the aprouver para a feitura de sua ficção, o que é ratificado pelas palavras de Autran Dourado, "Mesmo quando o romancista pretende que está retratando uma pessoa da vida real, que ele tenha conhecido, o que na verdade está fazendo não é retratar a pessoa real mas transpor para o romance uma figura que agora existe dentro dele [...]" (DOURADO, 1973, p. 103-104).

$O$ poeta construído para a narrativa de Miranda tem os traços conhecidos da biografia. Porém, o contexto social em que ocorre o enredo - repleto de tocaias, ciúmes, luxúria, poder e corrupção - exerce influência direta sobre os posicionamentos da personagem. Tal postura evidencia a visão de Goldmann ao tratar sobre a conversão de indivíduos problemáticos na sociedade:

No plano consciente e manifesto, a vida econômica compõe-se de pessoas orientadas exclusivamente para os valores de troca, valores degradados, aos quais se somam na produção alguns indivíduos - os criadores em todos os domínios - que se conservam orientados, essencialmente, no sentido dos valores de uso e que, por isso mesmo, situam-se à margem da sociedade e convertem-se em individuos problemáticos; e, naturalmente, como esses, a menos que aceitem a ilusão [...] romântica da ruptura total entre a essência e a aparência, entre a vida interior e a vida social, não lograriam furtar-se às degradações sofridas por sua atividade criadora na sociedade produtora para o mercado, a partir do instante em que essa atividade se manifeste exteriormente, se converta em livro, quadro, ensino, composição musical, etc. (GOLDMANN, 1967, p. 17, itálicos do original)

A paisagem se molda, também, para expor o contexto de existência da personagem protagonista, que é repleta de redutos sombrios, enegrecidos pelas traições conjugais e políticas, pela revolta velada, pela violência e pelos vícios. Aliás, nenhum segmento escapou da devassidão: igreja, população e governo.

Mesmo os que não tinham eira nem beira, nem
engenho, nem amiga, vestiam seda, punham
polvilhos. Eram esses os cristãos que vinham,
na maior parte, e esses os que caminhavam por
ali, tirando o chapéu e curvando-se à passagem
do governador. Eram também persas,
magores, arménios, gregos, infiéis e outros
gentios. Mermidônios, judeus e assírios, turcos
e moabitos. A todos, a cidade dava entrada.
(MIRANDA, 2006, p. 10)

Todos estão contaminados pela corrupção. $\mathrm{O}$ romance de Ana Miranda é uma representação do contexto histórico da Bahia do século XVII, pois exibe abundantemente a descrição dos espaços, das personagens e das organizações que formam um elo com a personagem protagonista, não para justificar seus atos, mas para evocar suas características mais latentes, a denúncia e a perversão:

"De que pode servir calar? Nunca se há de falar
o que se sente? Dizem que sou satírico e louco,
de língua má, de coração danado, mas os que
não mordem é porque não têm dentes. Os que
têm telhado de vidro não lançam pedras nas
telhas alheias. A mudez canoniza as bestas. Os
padres são uns filhos das putas" (MIRANDA,
2006, p. 113, aspas da autora)

Frequentador assíduo das camas das prostitutas e um crítico audaz do governo e da igreja, a alcunha de boca do inferno é justificada pelo comportamento do poeta durante todo o romance, o que corrobora com os apontamentos de Rosenfeld (1976), de que é a personagem que mais, nitidamente, torna patente a ficção, através dela a camada imaginária se adensa e se cristaliza. O poeta ficcionalizado encontra-se integrado em 
um denso tecido de valores de várias ordens, que revelados, como numa iluminação, atuam na plena concreção do ser humano individual;

\begin{abstract}
Ah, aquela desgraçada cidade, notável desaventura de um povo néscio e sandeu. Gregório de Matos foi informado sobre a morte do alcaide. Sofria ao ver os maus modos de obrar da governança, mas reconhecia que não apenas aos governantes, mas a toda a cidade, o demo se expunha. Não era difícil assinalar os vícios em que alguns moradores se depravavam. Pegou sua pena e começou a anotar (MIRANDA, 2006, p. 26).
\end{abstract}

Dessa forma, compreendemos que a convergência intencional entre espaço e personagem revela o quão desajustada e corrupta era a realidade da colonização brasileira. Ou seja, a ficção trabalhada por Miranda no século XX busca na aliança entre a personagem e o espaço as raízes de um processo político que vitimizou o país.

Tal consonância evidencia que em uma sociedade em que imperam a ganância e a corrupção, não pode haver justiça e pessoas resolutas. $\mathrm{Na}$ verdade, ela gera indivíduos problemáticos, que não conseguem conviver com o mundo que os cerca devido ao choque de valores. Gregório de Matos é um desses indivíduos, como um poeta que satiriza a realidade, demonstra sua insatisfação consigo, com o meio e com os outros. Para Lukács,

[a] estrutura dada do objeto - a busca é apenas a expressão, da perspectiva do sujeito, de que tanto a totalidade objetiva da vida quanto sua relação com os sujeitos nada têm em si de espontaneamente harmonioso - aponta para a intenção da configuração: todos os abismos e fissuras inerentes à situação histórica têm de ser incorporados à configuração e não podem nem devem ser encobertos por meios composicionais. Assim, a intenção fundamental determinante da forma do romance objetivase como psicologia dos heróis romanescos: eles buscam algo (LUKÁCS, 2000, p. 60).

No romance histórico de Ana Miranda, Gregório de Matos constitui a vitrine do desajuste entre o poeta e seu meio, principalmente porque na Bahia encontra-se o berço de inúmeras injustiças, onde envoltos pelos mais diversos vícios, não deixariam de se encantar por ela "fossem seres humanos, anjos ou demônios" (MIRANDA, 2006, p. 303).

O romance histórico de Ana Miranda traduz toda a corrupção dos seres e do meio, propondo com isso uma reflexão acerca das bases colonizadoras do país e os efeitos que essa colonização causou ao país e ao seu povo.

\section{Considerações finais}

Os romances históricos aqui analisados, mesmo que escritos em séculos diferentes, conseguem fazer o que Jameson mostra como uma das características indispensáveis para esse tipo de narrativa, "O romance histórico não deve mostrar nem existências individuais nem acontecimentos históricos, mas a interseção de ambos: o evento precisa trespassar e transfixar de um só golpe o tempo existencial dos indivíduos e seus destinos". (JAMESON, 2007, p. 192).

É justamente isso que ocorre tanto em $O$ Guarani quanto em Boca do Inferno, romances em que as personagens protagonistas são um dos três elementos de uma tríplice aliança profícua que inclui: protagonista - discurso histórico - ficção. A essa tríplice aliança são acoplados a construção do romance com suas particularidades - espaço, personagens secundárias, foco narrativo, tempo para que desse modo possa-se chegar ao desfecho que confere verossimilhança à obra e ao mesmo tempo propondo outros olhares que partem da historiografia, passam pela ficção e contribuem para o enfrentamento da realidade.

Assim, a ficção romanesca se estrutura nas lacunas do discurso historiográfico real e, nessa construção, a figura do protagonista é essencial, pois é ela quem orienta o preenchimento dessas lacunas. É por ela que se orienta o desenvolvimento das ações e as características desse Brasil em constantes conflitos políticos. 
Dessa forma, enquanto o romance de Alencar conta com um protagonista que transita entre as duas nacionalidades, constituindo-se como um herói que representa a ruptura entre as duas nações; o romance de Ana Miranda conta um herói problemático ou um anti-herói que evidencia os efeitos da colonização portuguesa, embebido pela sociedade corrompida pelos vícios.

Tanto a narrativa e a personagem protagonista de Alencar, quanto a de Ana Miranda são exímias representações da sociedade da época, evocando a formação do povo brasileiro e as condições em que ela ocorre.

\section{Referências}

ALENCAR, José. O Guarani. 14 ed. São Paulo: Melhoramentos, 1966.

BASTOS, Alcmeno. Tudo é invenção: outro conhecimento. Cândido, Jornal da biblioteca pública do Paraná, n. 39. Curitiba, out. de 2014. Disponível em: http://www.candido.bpp.pr.gov.br/modules/ conteudo/conteudo.php? conteudo $=750$. Acesso em: 10 fev. 2015.

BENJAMIN, Walter. Obras escolbidas III: Charles Baudelaire, um lírico no auge do capitalismo. São Paulo: Brasiliense, 1991.

CANDIDO, Antonio. A personagem do romance. In: CANDIDO, et. al. A personagem de ficção. 5 ed. São Paulo: Perspectiva, 1976. p. 53-80.

CANDIDO, Antonio. Literatura e sociedade: Estudos de teoria e história literária. 8 ed. São Paulo: T. A. Queiroz, 2000.

DOODY, Margaret. Dar um rosto ao personagem. Trad. Denise Bottman. In: MORETTI, Franco (org.). A cultura do romance. São Paulo: Cosac Naify, 2009. p. 563-592.

DOURADO, Autran. Uma poética de romance. São Paulo: Perspectiva, 1973.
ESTEVES, Antonio R. Considerações sobre o romance histórico: no Brasil, no limiar do século XXI. Revista de Literatura, História e Memória, vol. 4, n. 4, p. 53-66, 2008. Disponível em: < http:// e-revista.unioeste.br/index.php/rlhm/article/ view/1202>. Acesso em: 12 fev. 2015.

ESTEVES, Antonio R. O romance bistórico brasileiro contemporâneo: 1975-2000. São Paulo: Editora da UNESP, 2010.

GOLDMANN, Lucién. Sociologia do romance. Tradução de Álvaro Cabral. Rio de Janeiro: Paz e Terra LTDA, 1967.

HUTCHEON, Linda. Poética do pós-modernismo: história, teoria e ficção. Trad. Ricardo Cruz. Rio de Janeiro: Imago Ed, 1991.

JAMESON, Fredric. O romance histórico ainda é possível? Novos estudos - CEBRAP [online]. 2007, n.77, pp. 185-203. ISSN 0101-3300. Disponível em: $<$ http://www.scielo.br/scielo.php?pid=S0101$33002007000100009 \&$ script $=$ sci_abstract $>$. Acesso em: 8 mar. 2015.

LUKÁCS, Georg. O romance histórico. Trad. de Rubens Enderle. São Paulo: Boitempo, 2011.

LUKÁCS, Georg. A teoria do romance: um ensaio histórico-filosófico sobre as formas da grande épica. Trad. de José M. M. de Macedo. São Paulo: Duas Cidades; Editora 34, 2000.

MARTINS, Denis Pereira. Boca do Inferno. Literatura $\mathrm{x}$ história: uma interpretação do processo de criação de Ana Miranda. RELEGENS THRÉSKEIA: Estudos e pesquisa em religião, v. 04, n. 02, p. 168-179, 2015. Disponível em: http:// revistas.ufpr.br/relegens/article/view/43550. Acesso em: 10 fev. 2016.

MIRANDA, Ana. Boca do inferno. São Paulo: Companhia das Letras, 2006.

MORAIS, Eunice de. Fição e história no romance Boca do Inferno. Dissertação (Mestrado em Letras - Estudos Literários) - Ciências Humanas, Letras e Artes, Universidade Federal do Paraná, Curitiba. 2003. 
ROSENFELD, Anatol. Texto/contexto. São Paulo: Perspectiva, 1976.

WEINHARDT, Marilene. Considerações sobre o romance bistórico. Letras, Curitiba, n.43, p. 1123, 1994. Editora da UFPR. Disponível em:< ojs.c3sl.ufpr.br/ojs/index.php/letras/article/ download/19095/12396>. Acesso em 10 fev. 2015.

WOOD, James. Como funciona a fição. São Paulo: Cosac Naify, 2011.

Recebido em: 20 de setembro de 2017.

Aprovado em: 28 de outubro de 2017. 